Public health

\title{
ASSESSMENT OF THE EPIDEMIOLOGICAL SITUATION AND BURDEN OF COVID-19 ON GLOBAL, REGIONAL AND NATIONAL LEVEL
}

\author{
Aferdita Kurti-Karameta ${ }^{\text {, Fimka Tozija² }}$ \\ National Institute of Public Health of Kosovo, Prishtina, Kosovo \\ Institute of Public Health of Republic of North Macedonia; Ss. Cyril and Methodius University in Skopje, Faculty \\ of Medicine, Republic of North Macedonia
}

\begin{abstract}
Citation: Kurti-Karameta A, Tozija F.Assessmen of the epidemiological situation and burden of COVID-19 on global, regional and national level. Arch Pub Health 2021; 13 (2).

doi.org/10.3889/aph.2021.6004

Key words: COVID-19, SARS-CoV-2, assessment, epidemiological situation, burden

*Correspondence: AferditaKurti-Karameta, Na tional Institute of Public Health of Kosovo, Prishti na, Kosovo. E-mail:aferdita_kurti@hotmail.com

Received: 28-Fev-2021; Revised: 1-Jun-2021 Accepted: 5-Jun-2021; Published: 30-Jun-2021 Copyright: ${ }^{\odot}$ 2021. AferditaKurti-Karameta, Fimka Tozija. This is an open-access article distrib-uted under the terms of the Creative Commons Attribution License, which permits unrestricted use, distribution, and reproduction in any medium, provided the original author(s) and source are credited.

Competing Interests: The author have declared that no competing interests
\end{abstract}

\begin{abstract}
The current pandemic of corona virus disease 2019 (COVID-19) is an infectious disease caused by a newly discovered severe acute respiratory syndrome Coronavirus 2 (SARS-CoV-2). Global COVID-19 burden is characterized by a high variability in death rate across countries. Several possible explanations have been proposed, but it is not clear whether this variability is due to a single predominant factor or instead to multiple caus-es. The aim of this paper was to present and analyze the epidemiological situation and burden of the COVID-19 pandemic in Kosovo compared to other countries in Europe and the world. Material and methods: Public health approach and desk review were applied to present and analvze the trends over time of selected epidemiological indicators for COVID-19 based on multiple sources of data as well as WHO epidata and literature review. The assessment of the epidemiological situation in EU/EEA member states was done using the surveillance data routinely collected by ECDC. Official medical records from the National Institute of Public Health, other relevant health institutions; State Statistical Office and Ministry of Health in Kosovo were used. Results: According to ECDC as of 11 February 2021, 106,472,660 cases of COVID-19 (in accordance with the applied case definitions and testing strategies in the affected countries) have been report-ed, including 2,323,103 deaths. COVID-19 cases have been reported from: Africa: 3,673,181 cases, Asia: 20,438,608 cases, Europe: 34,681,426 cases, America: 47,620,931 cases; Oceania: 57,809 cases, Others: 705 cases. Deaths have been reported from: Africa 95,128 deaths, Asia 343,886, America 1,107,066, Europe 775,883, Oceania 1,210 and Other 6 deaths. In Kosovo from 13 March 2020 until 15th February 2021 there have been 64,298 cases of COVID- 19 with 1534 deaths. Absolute values of the indi-cators remain high in all countries in Europe, including those with stable or decreasing trends in these indicators, suggesting that transmission is still wide spread. The epidemic trajectory over the next months will be deter-mined by the balance of four factors, with many different outcomes possi-ble: the continued scale-up of vaccination, declining seasonality, the spread of new variants and increased behaviors that favor COVID-19 transmis-sion.Conclusion: Findings from this paper can help to develop evidence-based policy interventions in Kosovo for risk assessment of COVID-19 and protection of general population and especially vulnerable groups with higher risk from COVID 19
\end{abstract}

\section{Јавно здравје}

\section{ПРОЦЕНКА НА ЕПИДЕМИОЛОШКАТА СОСТОЈБА И ОПТОВАРЕНОСТА CO COVID-19НАГЛОБАЛНО, РЕГИОНАЛНО ИНАЦИОНАЛНО НИВО}

\author{
Афердита Курти-Карамета루, Фимка Тозија² \\ Начионален инсиичйуши за јавно зgравје, Пришйина, Косово

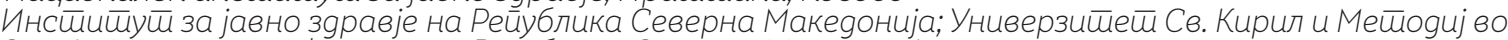 \\ скойје, меgицински факулйей, Рейублика Северна Макеgонија
}

\section{Цитирање:Курти-Карамета А, Тозија Ф.Про- ценка на епидемиолошката состојба и оптова- реноста со COVID-19 на глобално, регионално и национално ниво. Арх Ј Здравје 2021;13(2) \\ doi.org/10.3889/aph.2021.6004}

Клучни зборови:COVID-19, SARS-CoV-2, проценка, епидемиолошка состојба, оптовареност

*Кореспонденција:АфердитаКурти-Карамета, Национален институт за јавно здравје, Приштина, Косово. E-mail:aferdita_kurti@ hotmail.com

Примено: 28-фев-2021; Ревидирано: 1-јүн-2021; Прифатено: 5-јун-2021; Објавено: 30-јун-2021

Печатарски права: ${ }^{\circledR 2} 221$ 2021Афердита Курти-Карамета, Фимка Тозија. Оваа статија е со ол отворен пристап дистрибирана нод үсловите о нел неограничена унотреба, дистрибуција и репродукција на било кој медиум, доколку се цитираат оригиналниот(ите) автор(и) и изворот.

Конкурентски интереси: Авторот изјавува дека нема конкурентски интереси.

\section{Извадок}

Тековната пандемија со корона вирус од 2019г.(COVID-19) е инфективно заболување предизвикано од новооткриениот корона вирус 2 кој предизвикува тежок акутен респираторен синдром (Severe Acute Respiratory Syndrome Coronavirus 2 (SARS-CoV-2). Глобалниата оптовареност со COVID-19 се карактеризира со голема варијабилност во стапката на смртност во државите. Предложени се неколку можни објаснувања, но не е јасно дали оваа варијабилност се должи на единствен доминантен фактор или на повеќе причини. Целта на овој труд беше да се презентира и анализира епидемиолошката состојба и оптовареноста со пандемијата COVID-19 во Косово и да се спореди со другите земји во Европа и светот.Материјал и методи: Јавноздравствен пристап и прегледот на документи се применети за да се презентира и анализира трендот на избраните епидемиолошки индикатори за COVID-19 врз основа на податоци од повеќе извори, како и епидата на СЗО и преглед на литература. Проценката на епидемиолошката состојба во земіите-членки на EУ/EEA беше направена со користење на податоците за следење, рутински собрани од ЕСDС. Беа користени официјални медицински извештаи од Националниот институт за јавно здравје, други релевантни здравствени институции; Државниот завод за статистика и Министерството за здравство на Косово.Резултати: Според ЕСDС заклучно со 11 февруари 2021 година, во светот пријавени се 106.472.660 случаи на COVID-19 (во согласност со применетите дефиниции на случаи и стратегии за тестирање во погодените земји), вклучително и 2.323.103 смртни случаи. Пријавени се случаи со COVID-19 од: Африка: 3.673.181 случаи, Азија: 20.438.608 случаи, Европа: 34.681 .426 случаи, Америка: 47.620.931 случаи; Океанија: 57809 случаи, други: 705 случаи. Пријавени се смртни случаи од: Африка 95.128 смртни случаи, Азија 343.886, Америка 1.107.066, Европа 775.883, Океанија 1.210 и други 6 смртни случаи. Во Косово од 13 март 2020 година до 15 февруари 2021 година пријавени се 64.298 случаи на COVID-19 и 1.534 смртни случаи.Апсолутните вредности на индикаторите остануваат високи во сите земји во Европа, вклучително и оние со стабилни или трендови на опаѓање, што укажува дека трансмисијата е сѐ уште широко распространета. Текот на епидемијата во следните месеци ќе биде одреден од рамнотежата помеѓ четири фактори, со можни различни исходи: континуирано зголемување на вакцинацијата, сезонско намалување, ширење на новите варијанти на вирусот и зголемено однесување што придонесува за преносот на COVID-19.Заклучок: Наодите од овој труд можат да помогнат да се развијат политики и интервенции засновани на докази во Косово, за проценка на ризик за COVID-19 и заштита на општата популација и особено на ранливите групи со поголем ризик од COVID 19. 


\section{Introduction}

The current pandemic of coronavirus disease 2019 (COVID-19) is an infectious disease caused by a newly discovered severe acute respiratory syndrome Coronavirus 2 (SARS-CoV-2) ${ }^{1}$. Genetic se-quencing of the virus suggests that it is a betacoronavirus closely linked to the SARS virus. By way of definition, a symptomatic COVID-19 case is a person who has developed signs and symptoms suggestive of COVID-19. Symptomatic transmission refers to transmission of SARS-CoV-2 from persons with symptoms. Epidemiology and virologic studies suggest that transmission mainly occurs from symptomatic people to others by close contact through respiratory droplets, by direct contact with infected persons, or by contact with contaminated objects and surfaces $2,3,4,5$.

Most people infected with the COVID-19 virus will experience mild to moderate respiratory illness and recover without requiring special treatment. Around $30 \%$ of pregnant women with COVID-19 experienced preterm delivery, whereas the mean birth weight was $2855.9 \mathrm{~g}$. Fetal death and detec-tion of SARS-CoV-2 were observed in about $2 \%{ }^{6}$. Older people and those with underlying medical problems like cardiovascular disease, diabetes, chronic respiratory disease and cancer are more likely to develop serious illness ${ }^{7,8}$.

The cross-sectional study conducted on a sample of 69,054 university students in France showed self-reported prevalence of suicidal thoughts, severe distress, high level of perceived stress, severe depression, and high level of anxiety: $11.4 \%, 22.4 \%$, $24.7 \%$, $16.1 \%$, and $27.5 \%$, respectively. The following factors were associated with reporting at least 1 mental health outcome: female gender or nonbinary gender, precariousness, low-quality housing, history of psychiatric fol- low-up, symptoms compatible with COVID-19, social isolation and low quality of the information received ${ }^{9}$.

This pandemic is characterized by a high variability in death rate (defined as the ratio between the number of deaths and the total number of infected people) across world countries. Several possible explanations have been proposed, but it is not clear whether this variability is due to a single pre-dominant factor or instead to multiple causes ${ }^{10}$.

Since the outbreak of COVID-19 pandemic, several hypotheses have been proposed to explain the great variability in the death rate across countries. The Italian study provides evidence that one of the most crucial factors affecting the death rate is the availability of hospital beds ${ }^{11}$.

To date there is only one treatment, systemic corticosteroids, known to reduce mortality in patients with severe COVID-19, limiting treatment options and putting more pressure on supportive care alternatives such as oxygen support ${ }^{12}$.

There remains uncertainty around how effective a vaccine will be in reducing transmission and/or severity of illness or what duration of immunity it will confer, so it must be seen as a potential future tool to be used in conjunction with robust application of existing measures ${ }^{13}$.

The aim of this paper was to present and analyze the epidemiological situation and burden of the COVID-19 pandemic in Kosovo compared to other countries in Europe and the world from its be-ginning up to February 2021.

\section{Material and methods}

Public health approach and desk review were applied to present and analyze the trends over time of selected epidemio- 
logical indicators for COVID-19 based on multiple sources of data, as well as WHO epidata and literature review.

The assessment of the epidemiological situation in EU/EEA member states was done using the sur-veillance data routinely collected by ECDC and IHME. For all countries globally that have reported COVID-19 cases to date, the main indicator shown is the 14-day notification rate of reported COVID-19 cases per 100,000 population, which provides an estimate of the prevalence of active cases in the population. A 14-day notification rate of reported deaths per 1,000,000 population is also plotted on the time-series for each country to show trends in deaths compared to cases.

Data for Kosovo were used from official medical records from the $\mathrm{Na}-$ tional Institute of Public Health, other relevant health institutions, State Statistical Office and Ministry of Health of Kosovo.

\section{Results}

\section{Global situation}

In January 2020, the World Health Organization (WHO) declared the outbreak of the new coronavirus disease in Hubei Province, China as a public health emergency of international importance ${ }^{14}$. The WHO stated that there was a high risk of the spread of the new coronavirus disease (COVID-19) to other parts of the world 15. Since the start of the pandemics caused by SARS-CoV-2 and as of April 1, 2020, 206 countries have suffered from 885,344 cases and 44,214 deaths, with an average death rate of $4.99 \%$ 1. These numbers have been significantly increased and as of 01 November 2020, 46,382,791cases of COVID-19 (in accordance with the applied case definitions and testing strategies in the affected countries) have been reported, including 1,198,717deathsand recovered 30,927,352 ${ }^{16}$. Globally as of 24 January over 97 million COVID-19 cases and more than 2.1 million deaths have been reported by John Hopkins ${ }^{17}$. Distribution of cases of COVID-19 by continent (according to the applied case definition and testing strategies in the affected countries) is presented in Figure 1. ${ }^{18}$

Preliminary seroprevalence surveys in countries affected earlier in the outbreak have indicated that the pro-

Figure 1. Distribution of COVID-19 cases worldwide, as of week two 2021

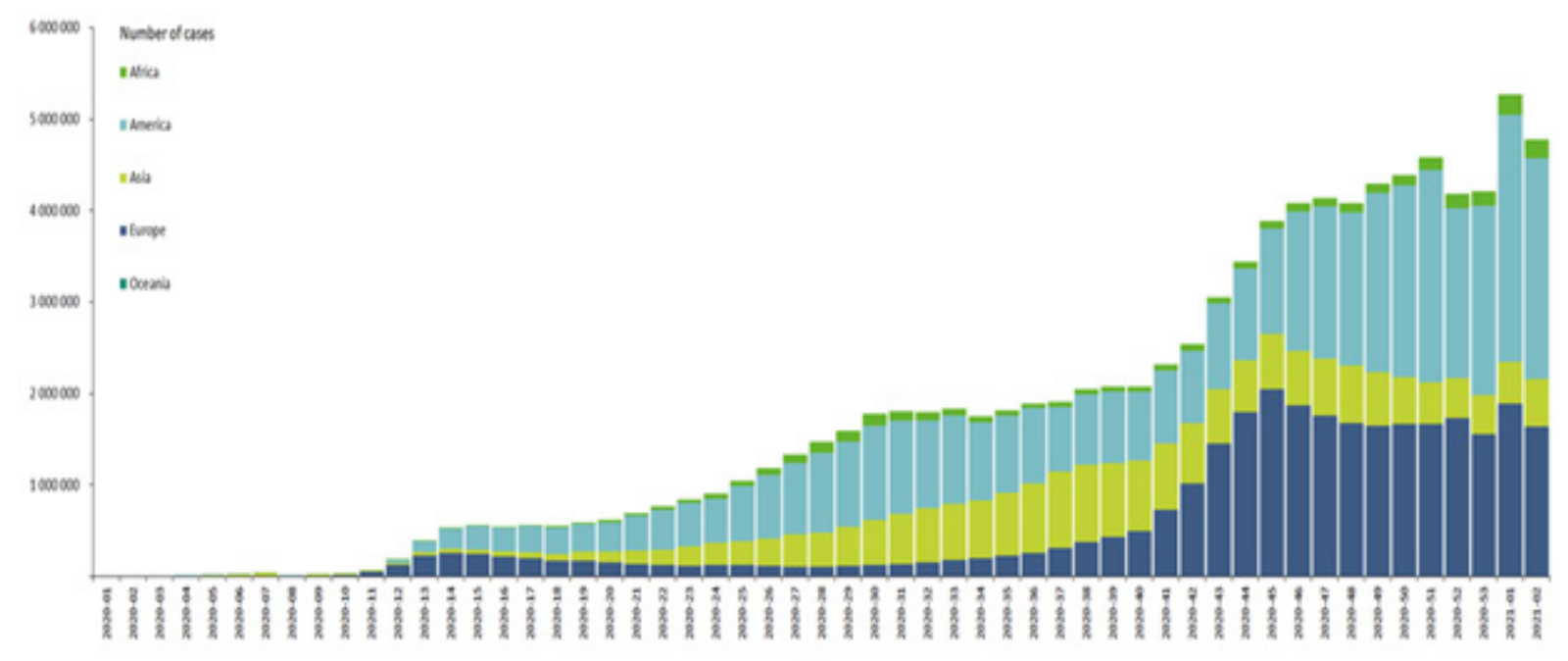

Source: European Centre for Disease Prevention and Control 
portion of people having been infected is low, with most surveys showing prevalence below $10 \%$, suggesting that most of the world's population remains susceptible to infection ${ }^{19}$.

According to ECDC20as of 11 February 2021, 106,472,660 cases of COVID-19 (in accordance with the applied case definitions and testing strategies in the affected countries) have been reported, in-cluding 2,323,103 deaths.
COVID-19 cases have been reported from: Africa: 3,673,181 cases, Asia: 20,438,608 cases, Europe: 34,681,426 cases, America: 47,620,931 cases; Oceania: 57,809 cases, Others: 705 cases. Deaths have been reported from: Africa 95,128, Asia 343,886, America 1,107,066, Europe 775,883, Oceania 1,210 and Other 6 deaths (Figure 2).

Figure 2. Distribution of COVID-19 deaths worldwide as of week 52021

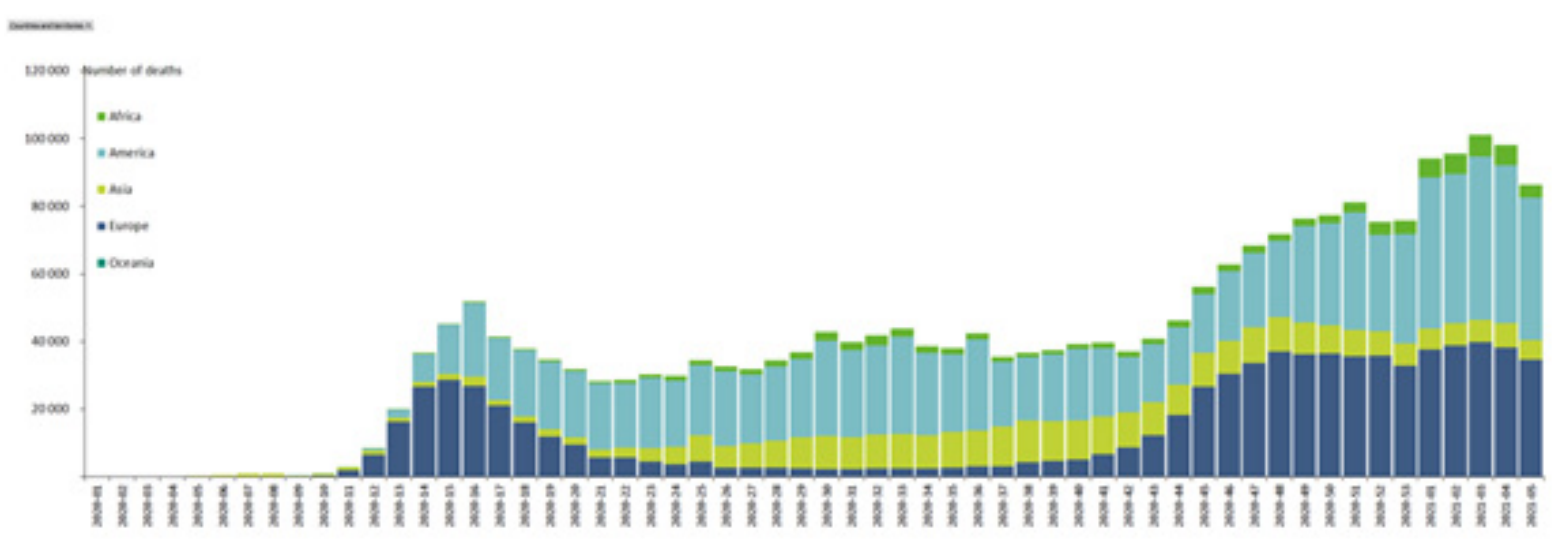

Source: European Centre for Disease Prevention and Control

\section{Situation with COVID-19 in Europe}

COVID-19 cases started increasing at the beginning of September driven by resurgence in the WHO European and Eastern Mediterranean regions that are surpassing levels reported during the first peak in March and April and there appears to be an acceleration of the pandemic globally. The cumulative cases increased for $18 \%$ to $10,552,074$ cases (from 8,913,201 cases on 23 October 2020) and cumulative deaths increased by $6 \%$ to 279,958 deaths (from 264,468 deaths on 23 October 2020). The 5 countries and territories with the highest percentage change in a 14-day cumulative case incidence are: Liechtenstein (442\%), San Marino (377\%),
Cyprus (357\%), Serbia (354\%), and Switzerland (321\%). ${ }^{18}$

As of 18 December, 31 of the 55 IHR States Parties and 2 territories reporting cases in the WHO European Region have shown 14days incidence $>400$ per 100,000 population: $>701$ \{Lithuania $(1,327)$, Georgia (1,284), Serbia $(1,284)$, Luxembourg $(1,214)$, Croatia $(1,151)$, Slovenia (994), San Marino (989), Jersey (900), Sweden (837), Montenegro (837), Lichtenstein (807), Andorra (728), \{601 - 700 -Switzerland (688), Czech Republic (677), Denmark (670), 501 - 600 - Hungary (598), Netherlands (597), Slovakia (593), Azerbaijan (575), Portugal (538), North Macedonia (529), Turkey (515), 401 500 \{Estonia (498), Republic of Mol- 
dova (485), Latvia (484), Bulgaria (473), Romania (440), Austria (436), Cyprus (428), Armenia (425), United Kingdom (407), Poland (407)\} $\}^{18}$.

In Europe 10,866,134 cases have been reported; the five countries reporting most cases are: Russia $(1,673,686)$, France $(1,502,763)$, Spain $(1,259,366)$, United Kingdom $(1,073,882)$ and Italy $(759,829)$. 277,125 deaths have been reported in Europeand the five countries reporting most deaths are: United Kingdom $(47,250)$, Italy $(39,412)$, France $(38,289)$, Spain $(36,495)$ and Russia $(28,828)^{18}$.

By the end of week 3 (ending Sunday 24 January 2021), the 14-day case notification rate for the EU/ EEA, based on data collected by ECDC from official national sources from 30 countries, was 421 (country range: 26-1 429) per 100000 population, decreasing for one week. Among 29 coun-tries with high case notification rates (at least 60 per 100,000), an increase was observed in four countries (Finland, France, Portugal and Spain). Pooled data from 20 countries for the same week show that there were $1.6 \mathrm{pa}^{-}$ tients per 100,000 population in ICU due to COVID-19, which is $76 \%$ of the peak ICU occupancy observed during the pandemic. Pooled weekly ICU admissions based on data from 15 countries were 3.6 new admissions per 100 000, which is $42 \%$ of the peak rate to date. The 14-day COVID-19 death rate for the EU/EEA, based on data collected by ECDC from official national sources from 30 countries, was 103.2 (country range: 0.0-247.6) per million popula-tion. The rate has been stable for nine weeks. Among 29 coun- tries with high 14-day COVID-19 death rates (at least 10 per million), an increase was observed in four countries (Ireland, Portugal, Slovakia and Spain). ${ }^{20}$

Despite the spread of new variants, daily reported cases have declined since earlyJanuary, to 169,300 per day on average in the last analyzed week compared to 198,400 the week before (Figure 3). Daily deaths in the last week decreased to 6,470 per day on average compared to 6,790 the week before (Figure 4). COVID-19 is number 1 cause of death in the European Region with 45,311 weekly deaths, followed by ischemicheartdisease with 44,253 deaths and stroke with 22,622 deaths. IHME estimation is that $12 \%$ of people in the European Region have been infected as of February 8, while in some countries or regions more than $20 \%$ have been infected: Portugal, parts of Spain, Czech Republic, Bosnia and Herzegovina, North Macedonia, Moldova, Armenia, and Azerbaijan. The infection detection rate in the region remains around $45 \%$. The daily death rate is greater than 4 per million in 32 countries $^{21}$.

\section{Situation in the Balkans}

Across the region of the Western Balkans, the situation with the COVID-19 pandemic is deteriorating, with a significant rise in infections and deaths (doubling rates) in almost every country (Monte-negro 377 per 100,000, North Macedonia 355, Bosnia and Herzegovina 332) (Figure 5).

Further spread of COVID-19 is very high and the epidemic in North Macedonia is in wide commu-nity spread. Extreme adherence to precautions and government preventive instructions is 
Figure 5. Distribution of COVID-19 deaths worldwide as of week 52021

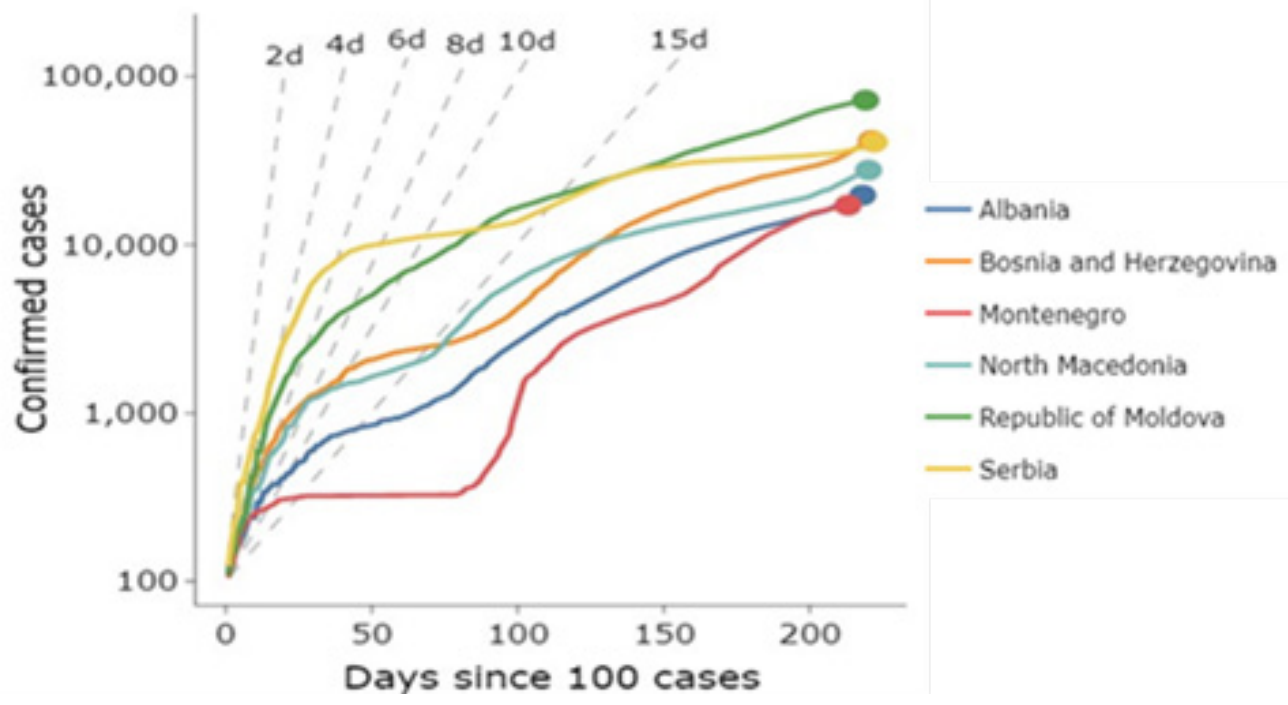

Source: Source: World Health Organization

required. North Macedonia was seeing sustained daily decrease in new cases: $\mathrm{MOH}$ reported 91,161coronavirus positive cases, 2,812 deathsand 79,621 recovered, as of 25thJanuary $2021^{22}$.

\section{Situation in Kosovo}

In Kosovo,on 13th of March 20201, the first two cases were confirmed, a 77 year old man from Vitia and an Italian woman in her early 20s, who worked in Klina with Caritas Kosovo. The Gov-ernment of Kosovo decided to quarantine and block the entrances and exits of these two cities. On $14^{\text {th }}$ of March, the third case was confirmed, a family member of the 77 year old from Vitia tested positive for coronavirus. On the same day, two other new cases were confirmed, a 42 year old man from Vitia and a 37 year-old woman from Malisheva. After the first case emerged in Malisheva, the Prime MinisterAlbin Kurti decided to quarantine the municipality. From 1 July until 31 July we had increased number of infected people with coronavirus, bringing the total number of 2,878 positive cases, 1,577 recoveries and 51 death

Figure 6. COVID-19 new cases per week in Kosovo

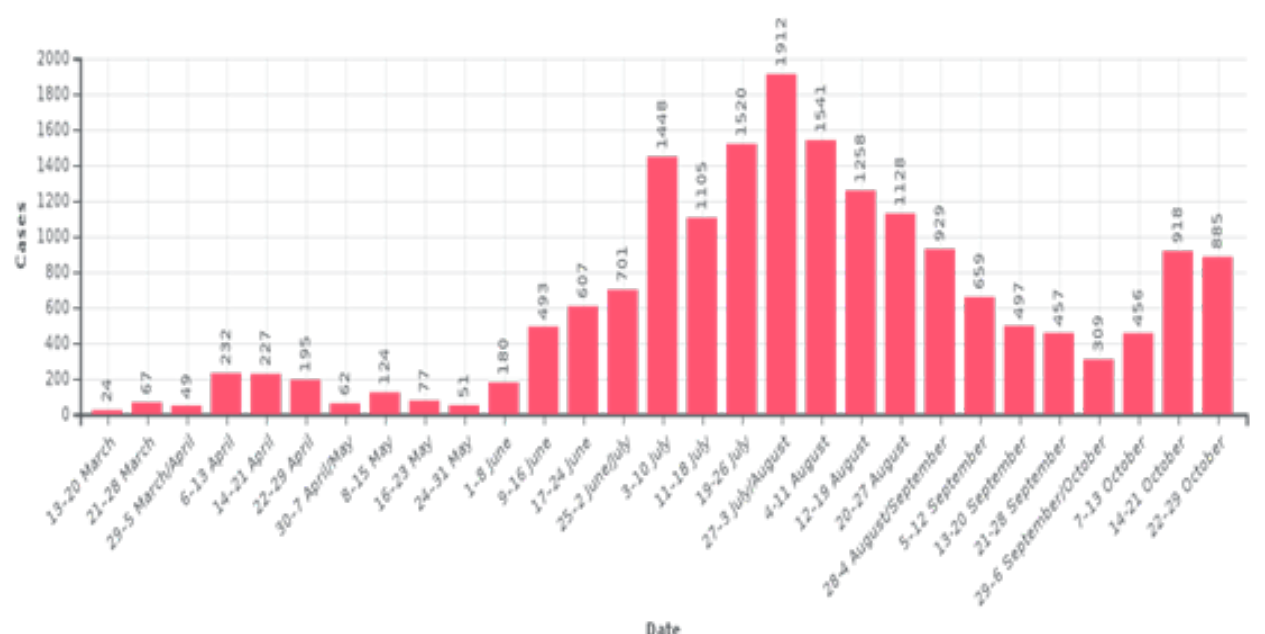


Figure 7. COVID-19 new deaths per week in Kosovo

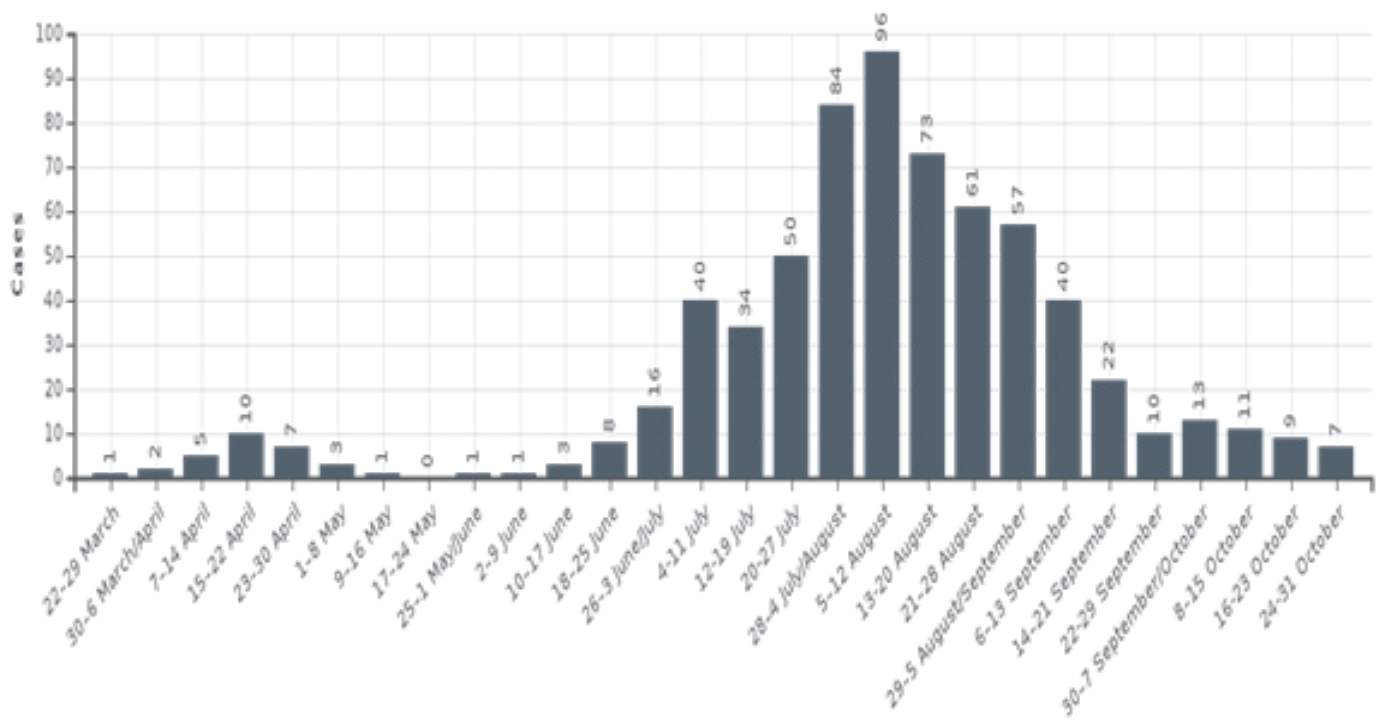

Date

Figure 8. COVID-19 number of cases by district in Kosovo

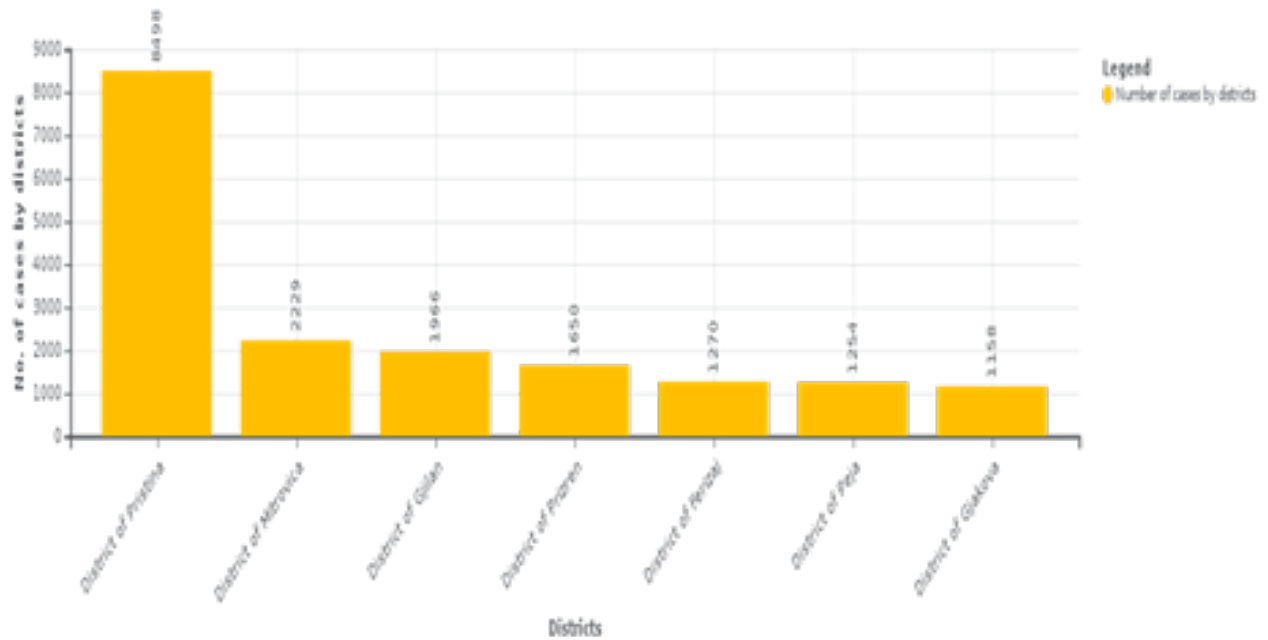

Figure 9. COVID-19 number of deaths by district in Kosovo

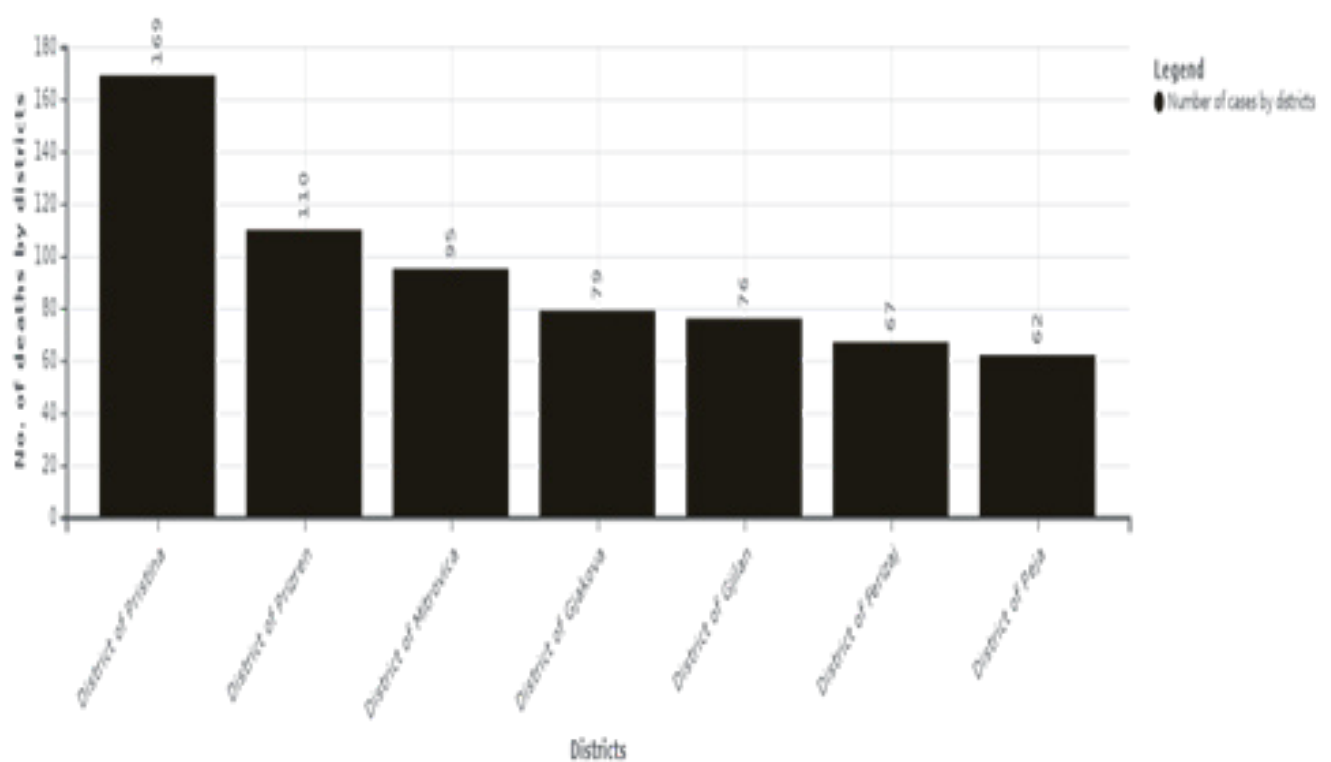

Source: National Institute of Public Health of Kosovo 
cases. In August, there was a total of 13,454 positive cases, 9,585 recoveries and 525 death cases.On 1 September, eight new death cases with coronavirus were confirmed, in total 533 deaths and 147new positive cases i.e. 13,601 in total (Figure 6, 7, 8. 9).23

While the number of new COVID-19 cases in Kosovo rose sharply in November 2020, with a week-ly average of 715 new cases, the number started to significantly decline from mid-December. In January 2021, Kosovo recorded a weekly average of 300 new cases, bringing the total number of reported cases to more than 58,000 since the beginning of the epidemic ${ }^{24}$.

On 2ndof February 2021 the $\mathrm{MOH}$ reported three deaths related to COVID-19 in the last 24 hours, bringing the death toll to 1,506. Meanwhile, 245 new cases were reported - 60,745 since the begin-ning of the pandemic. About 238 thousand people have been tested (2,615 in the last 24 hours). 189 people recovered in the last 24 hours- 52,810 in total. There are 6,429 active cases in the country. As of $15^{\text {th }}$ February 2021 there have been 64,298 cases of COVID- 19 with 1534 deaths. ${ }^{25,26}$

\section{Discussion}

While deaths in the European region were lower than observed in the earlier peak, given the time between cases and deaths, it is anticipated that deaths will continue to increase in the weeks ahead. Compared with the Northern Hemisphere spring, there has been a slower rise in deaths as cases have increased in the European region, as more cases are being reported among younger populations due to increased access to testing and increased social mixing. However, again more cases are starting to be reported amongst older age groups, which may lead to an increase in deaths in the coming weeks. Early in their outbreaks, many affected countries implemented strict control measures that were maintained for many months, some until a substantial decrease in transmission was observed. Public health interventions to the recent resurgence has lagged in many countries and have had a limited impact, so that many countries are now attempting short "circuit breaker" movement restrictions to interrupt transmission. Majority of countries in Europe are currently re-imposing restriction measures and limiting travel and social gatherings ${ }^{20}$. New mandates have been imposed in Austria, France, Greece, Kyrgyzstan, Luxembourg, the Netherlands, and Poland. Mandates have been lifted inAus-tria, Estonia, and Greece ${ }^{21}$.

The Government of Kosovo has undertaken measures in place to help contain the spread of the COVID-19 virus; restrictions on freedom of movement remain in place across the country for people over the age of 65 , who are only permitted to leave the house between 06:00-10:00 and 16:00-19:00. Weddings and religious ceremonies continue to be prohibited, while funerals may only be conducted with immediate family members. Since $23^{\text {rd }}$ of December 2020, controls at the borders also remain in force for both Kosovo citizens and most foreign nationals who are still required to present a negative PCR test when entering Kosovo, or undergo a seven-day selfisolation period following arrival. On 15th of January 2021, regulations governing public gatherings have, however, been re- 
laxed throughout Kosovo. The number of people permitted to gather in public spaces such as parks, squares and recreational centers has been extended from four to fifty. With Kosovo's parliamentary election scheduled for 14 February, a special mention was also made for public rallies, which must be limited to 50 persons. Municipalities have continued to be designated as low, medium or high risk depending on the number of infected inhabitants (150 infected individuals per 100,000 inhabitants respectively). Depending on their classification, municipalities face different measures. In low and medium-risk municipalities, operating hours for businesses, shopping centers and cultural institutions have now been extended by two hours to between 05:00 and 22:00. In high-risk municipalities, a curfew remains in force but has been pushed back, now applying from 21:30 until 05:00. Acting Prime Minister announced that vaccinations against COVID-19 will begin in February, with health professionals, people over the age of 65 and at-risk groups being the first to receive the vaccine. Estimations are that 20,000 citizens will be vaccinated per day. Agreements were reached with Pfizer/BioNTech, COVAX, and the Austrian state to provide vaccines ${ }^{25}$.

Absolute values of the indicators remain high in all countries, including those with stable or decreas-ing trends in these indicators, suggesting that transmission is still wide spread. Although in most countries indicators show an improving epidemiological situation, in a number of countries reporting increasing case trends it is likely that hospitalisations and ICU admissions, and potentially deaths, will increase in the coming weeks. $^{20}$

Daily cases have declined in the European Region, but daily deaths have declined only slightly. The epidemic trajectory over the next four months will be determined by the balance of four factors, with many different outcomes possible. Two factors are driving down transmission: the continued scale-up of vaccination, helped by the fraction of adults willing to accept the vaccine reaching 68\% (from 31\% in Kazakhstan to 91\% in Denmark); and declining seasonality, which will contribute to declining transmission potential until August. Two factors, however, can slow or even reverse the declines that have begun: the spread of variants B.1.1.7 and B.1.351, and increased behaviors that favor COVID-19 transmission. Community transmission of B.1.1.7 and B.1.351 has been confirmed in many countries and will inevitably spread more widely. In places where both variants have been detected at the same time, such as Belgium, B.1.1.7 is spreading faster than B.1.351. Despite the spread of these more transmissible variants, lockdowns have been effective in reducing transmission where imposed. If daily case counts continue to decline and vaccination increases, behaviors are likely to change, but data on this change are currently very limited. In the reference scenario, putting all these factors together, IHME estimated that: daily infections will decline reaching below 200,000 by early April, 21 countries will have high or extreme stress on hospital beds, while 32 countries will have high or extreme stress on ICU capacity, cumulative deaths will reach 1.4 million by June 12021 (388,000 additional deaths from February 8 to June 1) ${ }^{21}$. 
While countries have adopted policy measures with unprecedented speed and scope, the Monitor highlights some key challenges ahead 27: Finding the right balance and sequencing of health, eco-nomic and social and policy interventions to produce optimal sustainable labor market outcomes; Implementing and sustaining policy interventions at the necessary scale when resources are likely to be increasingly constrained; Protecting and promoting the conditions of vulnerable, disadvantaged and hard-hit groups to make labor markets fairer and more equitable; Securing international solidari-ty and support, especially for emerging and developing countries; Strengthening social dialogue and respect for rights.

In managing occupational risks of Covid-19, employers must control exposure to the virus so far as is reasonably practicable, taking into account the possibility that some workers will be more vulnera-ble than others should they contract the disease. Strategies may include changes to the way in which work is carried out, use of barriers and personal protective equipment (PPE), and in some cases, ex-clusion or redeployment of individuals who are more vulnerable. The need for selective exclu-sion/ redeployment of vulnerable workers will depend on the likelihood of their contracting Covid-19 through their work (which will vary according to the job and the prevalence of infection in the local community), and on the extent of their personal vulnerability to severe illness should they get the disease.

\section{Conclusion}

Findings from this study can help to develop evidence-based policy interventions in Kosovo for risk assessment of COVID-19 and protection of general population and especially vulnerable groups with higher risk of COVID 19, in line with the WHO's 3 key messages at UN General Assembly: Equitable access to COVID-19 tools; Maintaining momentum on the Sustainable Development Goals and Preparing for the next pandemic now.

\section{References}

1. COVID-19 Coronavirus Pandemic. Coronavirus-Worldometer website. https://www.worldometers.info/ coronavirus/. Accessed November 1 , 2020.

2 Burke RM, Midgley CM, Dratch A, Fenstersheib M, Haupt T, Holshue $\mathrm{M}$, et al. Active monitoring of persons exposed to patients with confirmed COVID19 - United States, January-February 2020. MMWR Morb Mortal Wkly Rep. 2020.

3 Ong SWX, Tan YK, Chia PY, Lee TH, Ng OT, Wong MSY, et al. Air, Surface Environmental, and Personal Protective Equipment Contamination by Severe Acute Respiratory Syndrome Coronavirus 2 (SARS-CoV-2) From a Symptomatic Patient. JAMA. 2020. Epub 2020/03/05.

4 Lauer SA, Grantz KH, Bi Q, Jones FK, Zheng Q, Meredith HR, et al. The incubation period of Coronavirus Disease 2019 (COVID-19) from publicly reported confirmed cases: estimation and application. Ann Intern Med 2020. Epub 2020/03/10.

5 Liu Y, Yan LM, Wan L, Xiang TX, Le A, Liu JM, et al. Viral dynamics in 
mild and severe cases of COVID-19. Lancet Infect Dis 2020. Epub 2020/03/23.

6 Yee J, Kim W, Han JM et al. Clinical manifestations and perinatal outcomes of pregnant women with COVID-19: a systematic review and meta-analysis. Sci Rep 2020;10:18126

7 Ceccarelli M, Berretta M, Venanzi Rullo E, Nunnari G, Cacopardo B. Differences and similarities between Severe Acute Respiratory Syndrome (SARS)-CoronaVirus $(\mathrm{CoV})$ and SARS-CoV-2. Would a rose by another name smell as sweet? Eur Rev Med Pharmacol Sci 2020;24(5):2781-2783.

8 Centers for Disease Control. Available at https://www.cdc.gov/coronavirus/2019-ncov/symptoms-testing/symptoms.html Accessed on 1 September 2020.

9 Wathelet M, Duhem S, Valva G et al. Factors associated with mental health disorders among university students in france confined during the COVID-19 pandemic. JAMA Network Open; October 23, 2020).

10 Reynolds M. What is coronavirus and how close is it to becoming a pandemic?. Wired UK. ISSN 13570978.

11 Bigiani L, Bigiani S, Bigiani A. How to minimize the impact of pandemic events: lessons from the COVID-19 crisis. Int J Health Policy Manag 2020;9(11):469-474.

12 Stockman LJ, Bellamy R, Garner P. SARS: systematic review of treatment effects. PLoS Med 2006;3(9):e343.

13 Jeyanathan M, Afkhami S, Smaill F. et al. Immunological considerations for COVID-19 vaccine strategies. Nat Rev Immunol 2020; 20:615-632.

14 https://www.euro.who.int/en/ health-topics/health-emergencies/ coronavirus-covid-19 Accessed on 31st October 2020.

15 https://www.burden-eu.net/news/ latest-news/212-publication-of-aburden-eu-guide-on-calculatingcovid-19-dalys?idU=1 Accessed on 21st October 2020.

16 Thonmoy Dey, Ankit Sinha.Ethnicity and COVID-19 - A commentary on "World Health Oganization declares global emergency: A review of the 2019 novel coronavirus (COVID-19)" (Int J Surg 2020;76:71-6).

17 John Hopkins.The Center for Systems Science and Engineering. Available at https://www. arcgis.com/apps/opsdashboard/ index.html\#/bda $7594740 \mathrm{fd}$ 40299423467b48e9ecf6 Accessed on 25 January 2021.

18 ECDC. Available at https://www. ecdc.europa.eu/en/geographical-distribution-2019-ncov-cases Accessed on 3rd February 2021.

19 WHO. Available at https:// www.who.int/director-general/ speeches/detail/who-directorgeneral-s-opening-remarks-atthe-media-briefing-on-covid-19--12-october-2020 Accessed on 31st October 2020.

20 ECDC. COVID-19 Country overview. Available at https://covid19-country-overviews.ecdc.europa.eu/ Accessed on 3rd February 2021.

21 Institute for Health Metrics and Evaluation. COVID-19 Results Briefing WHO. European Region. (Available at https://covid19. healthdata.org/global?view=to- 
tal-deaths\&tab=trend Accessed on $28^{\text {th }}$ February 2021)

22 https://www.worldometers.info/ coronavirus/country/macedonia/ Accessed on 26th January 2021.

23 https://en.wikipedia.org/ wiki/2020_coronavirus_pandemic_in_Kosovo Accessed on 10th September 2020.

24 https://exit.al/en/2021/01/26/kosovo-covid-19-update-26-january-5deaths-288

25 OECD. The COVID-19 Crisis in Kosovo. 31st January 2021. (Available at https://www.oecd.org/south-easteurope/COVID-19-Crisis-in-Kosovo. pdf Accessed on February $5^{\text {th }}$ )

26 ECDC. Available at:https://www. ecdc.europa.eu/en/geographical-distribution-2019-ncov-cases Accessed on February 5th 2021.

27 SOM. Returning to theworkplace after theCOVID-19 lockdownA toolkit. (Available at https://alama.org. uk/wp-content/uploads/2020/05/ Returning_to_the_workplace_ COVID-19_toolkit_FINAL.pdf Accessed on 28th February 2021) 